\title{
Formation and Mechanical Strength of Bulk Glassy Alloys in $\mathrm{Zr}-\mathrm{Al}-\mathrm{Co}-\mathrm{Cu}$ System
}

\author{
Tao Zhang and Akihisa Inoue \\ Institute for Materials Research, Tohoku University, Sendai 980-8577, Japan
}

\begin{abstract}
By choosing a new alloy composition of $\mathrm{Zr}_{55} \mathrm{Al}_{20} \mathrm{Co}_{20} \mathrm{Cu}_{5}$, we succeeded in forming bulk glassy alloys in rod and sheet forms by copper mold casting. The maximum diameter and sheet thickness were $5 \mathrm{~mm}$ and $3 \mathrm{~mm}$, respectively. The $T_{\mathrm{g}}, \Delta T_{\mathrm{x}}$ and $T_{\mathrm{g}} / T_{1}$ are $750 \mathrm{~K}, 80 \mathrm{~K}$ and 0.60 , respectively, being independent of sample thickness. The bulk alloy sheet exhibits Young's modulus of $92 \mathrm{GPa}$, elastic elongation limit of $2.1 \%$ and high tensile strength of $1960 \mathrm{MPa}$. These strength values are considerably higher than those for the other Zr-based bulk glassy alloys reported up to date. The synthesis of the new Zr-based bulk glassy alloy with high glass-forming ability and high tensile strength approaching $2000 \mathrm{MPa}$ is expected to result in a future extension of application fields as a high strength material.
\end{abstract}

(Received February 28, 2002; Accepted April 5, 2002)

Keywords: bulk glassy alloy, new zirconium base system, glass-forming ability, glass transition temperature, mechanical strength

\section{Introduction}

Since Zr-based glassy alloys with a large supercooled liquid region before crystallization were found in $\mathrm{Zr}-\mathrm{Al}-\mathrm{Ni},{ }^{1)}$ $\mathrm{Zr}-\mathrm{Al}-\mathrm{Ni}-\mathrm{Cu}^{2)}$ and $\mathrm{Zr}-(\mathrm{Ti}, \mathrm{Nb})-\mathrm{Al}-\mathrm{Ni}-\mathrm{Cu}^{3)}$ systems and the high thermal stability of the supercooled liquid caused the formation of bulk glassy Zr-based alloys with good mechanical properties, much attention has been paid to bulk glassy alloys. It has subsequently been reported that bulk glassy alloys with good mechanical properties are formed in the other $\mathrm{Zr}$ based alloy systems such as $\mathrm{Zr}-\mathrm{Ti}-\mathrm{Be}-\mathrm{Ni}-\mathrm{Cu},{ }^{4)} \mathrm{Zr}-(\mathrm{Pd}, \mathrm{Ta})-$ $\mathrm{Al}-\mathrm{Ni}-\mathrm{Cu}^{5)}$ and $\mathrm{Zr}-\mathrm{Al}-\mathrm{Be}-\mathrm{Ni}-\mathrm{Cu}^{6)}$ systems. These $\mathrm{Zr}$-based bulk glassy alloys exhibit high tensile fracture strength of 1500 to $1700 \mathrm{MPa}$ and have been used as sporting goods materials and connecting tubes for optical communication fibers. $^{7-10)}$ As is the case for the Zr-based bulk glassy alloys, $\mathrm{Ln}-\mathrm{Al}-(\mathrm{Co}, \mathrm{Ni}, \mathrm{Cu})^{11)}$ and $\mathrm{Pd}-\mathrm{Cu}-\mathrm{Ni}-\mathrm{P}^{12)}$ bulk glassy alloys possess good mechanical properties as is evidenced from much higher tensile fracture strength as compared with those for the corresponding crystalline alloys. However, there have been no data on bulk glassy alloys in Zr-, Ln- and Pd-based systems exhibiting high tensile fracture strength of about $2000 \mathrm{MPa}$. Very recently, we have found new $\mathrm{Cu}^{-13-15)}$ and $\mathrm{Ni}^{-16}{ }^{16}$ based bulk glassy alloys with high tensile fracture strength exceeding $2500 \mathrm{MPa}$. Simultaneously, we have investigated a dominant factor for achievement of high tensile fracture strength. It has been pointed out that the tensile fracture strength has a strong correlation with glass transition temperature $\left(T_{\mathrm{g}}\right)$ and liquidus temperature $\left(T_{1}\right)$ and there is a clear tendency for tensile strength to increase with increasing $T_{\mathrm{g}}$ and $T_{1}{ }^{13-16)}$ Based on the strong correlation, we have searched for a new Zr-based bulk glassy alloy with much higher tensile fracture strength. As a result, it was found that high tensile fracture strength of approximately $2000 \mathrm{MPa}$ is obtained for a number of bulk glassy alloys in $\mathrm{Zr}-\mathrm{Al}-\mathrm{Co}$ base systems such as $\mathrm{Zr}-\mathrm{Al}-(\mathrm{Co}, \mathrm{Fe}), \mathrm{Zr}-\mathrm{Al}-(\mathrm{Co}, \mathrm{Cu}), \mathrm{Zr}-\mathrm{M}-\mathrm{Al}-$ $(\mathrm{Co}, \mathrm{Fe}), \mathrm{Zr}-\mathrm{Al}-(\mathrm{Co}, \mathrm{Fe}, \mathrm{Ni}), \mathrm{Zr}-\mathrm{M}-\mathrm{Al}-(\mathrm{Co}, \mathrm{Fe}, \mathrm{Cu}), \mathrm{Zr}-\mathrm{Al}-$ $(\mathrm{Co}, \mathrm{Ni}, \mathrm{Cu})$ and $\mathrm{Zr}-\mathrm{M}-\mathrm{Al}-(\mathrm{Co}, \mathrm{Ni}, \mathrm{Cu})(\mathrm{M}=\mathrm{Ti}, \mathrm{Nb}, \mathrm{Ta})$ systems. This paper presents the glass transition temperature $\left(T_{\mathrm{g}}\right)$, crystallization temperature $\left(T_{\mathrm{x}}\right)$, supercooled liquid re- gion $\left(\Delta T_{\mathrm{x}}=T_{\mathrm{x}}-T_{\mathrm{g}}\right)$ and reduced glass transition temperature $\left(T_{\mathrm{g}} / T_{1}\right)$ of a $\mathrm{Zr}_{55} \mathrm{Al}_{20} \mathrm{Co}_{20} \mathrm{Cu}_{5}$ glassy alloy and the formation tendency and mechanical properties of the bulk glassy Zr-based alloy.

\section{Experimental Procedure}

A multi-component $\mathrm{Zr}_{55} \mathrm{Al}_{20} \mathrm{Co}_{20} \mathrm{Cu}_{5}$ alloy was examined because its alloy had the largest $\Delta T_{\mathrm{x}}$ in $\mathrm{Zr}_{55} \mathrm{Al}_{20} \mathrm{Co}_{25-x} \mathrm{Cu}_{x}$ ( $x=0,5,10,15,20$ and 25 at\%) alloy series. The alloy composition represents the nominal composition of the mixture. The alloy ingot was prepared by arc melting the mixture of pure metals in an argon atmosphere. Bulk glassy alloys in rod and sheet forms were produced by copper mold casting and melt-clamp die forging, respectively. The sample dimension was $70 \mathrm{~mm}$ in length and 2 to $5 \mathrm{~mm}$ in diameter for the cast rods and $2 \mathrm{~mm}$ in thickness, $50 \mathrm{~mm}$ in width and $70 \mathrm{~mm}$ in length for the forged sheets. A glassy alloy ribbon with a cross section of $0.02 \times 1.2 \mathrm{~mm}^{2}$ was also produced by melt spinning. The glassy phase was identified by $\mathrm{X}$-ray diffraction and optical and transmission electron microscopies (OM and TEM). Thermal stability was examined by differential scanning calorimetry (DSC) at a heating rate of $0.67 \mathrm{~K} / \mathrm{s}$. The melting and liquidus temperatures $\left(T_{\mathrm{m}}\right.$ and $\left.T_{1}\right)$ were measured with a differential thermal analyzer (DTA) at a cooling rate of $0.33 \mathrm{~K} / \mathrm{s}$. Mechanical properties were measured in tensile and compressive deformation modes with an Instron testing machine. The gauge dimensions were $1 \mathrm{~mm}$ in thickness, $5 \mathrm{~mm}$ in width and $15 \mathrm{~mm}$ in length for the tensile specimen and $2 \mathrm{~mm}$ in diameter and $4 \mathrm{~mm}$ in length for the compressive specimen, respectively. The strain rate was $5.0 \times 10^{-4} \mathrm{~s}^{-1}$ for the tensile deformation and $2.5 \times 10^{-3} \mathrm{~s}^{-1}$ for the compressive deformation. Fracture surface was examined by scanning electron microscopy (SEM).

\section{Results}

Figure 1 shows $\mathrm{X}$-ray diffraction patterns of the cast $\mathrm{Zr}_{55} \mathrm{Al}_{20} \mathrm{Co}_{20} \mathrm{Cu}_{5}$ samples in a rod form of 3 and $5 \mathrm{~mm}$ in diameter and in a sheet form of $2 \mathrm{~mm}$ in thickness. The patterns 


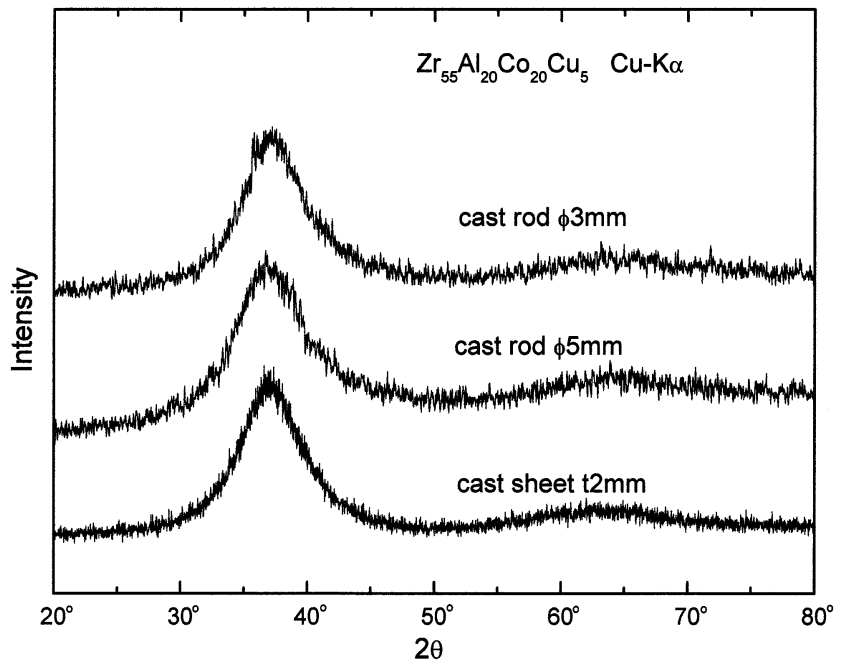

Fig. $1 \mathrm{X}$-ray diffraction patterns of $\mathrm{Zr}_{55} \mathrm{Al}_{20} \mathrm{Co}_{20} \mathrm{Cu}_{5}$ alloy in a rod form of 3 and $5 \mathrm{~mm}$ in diameter and a sheet form of $2 \mathrm{~mm}$ in thickness.

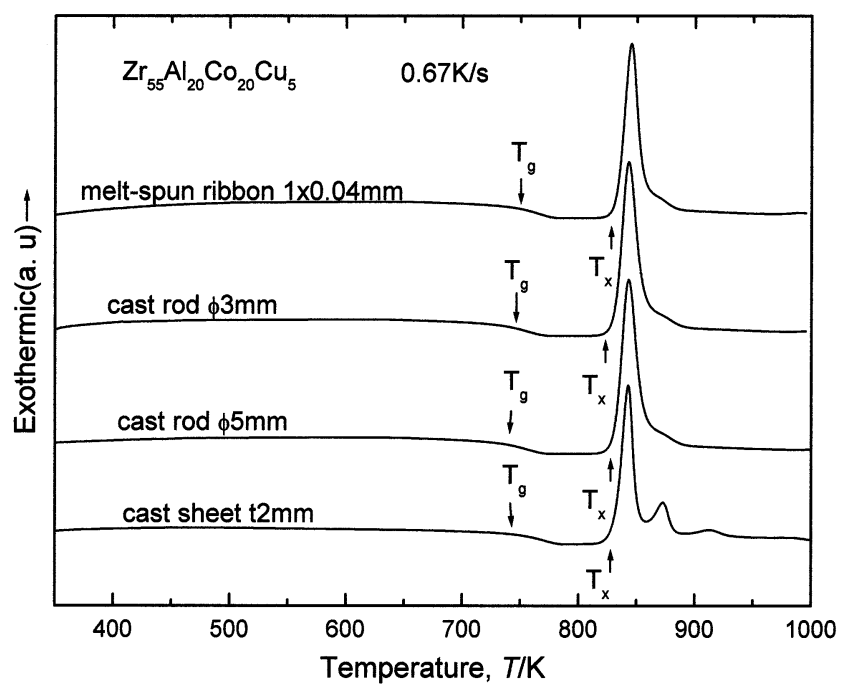

Fig. 2 DSC curves of the glassy $\mathrm{Zr}_{55} \mathrm{Al}_{20} \mathrm{Co}_{20} \mathrm{Cu}_{5}$ alloy in the rod and sheet forms.

consist only of a broad peak with a wave vector of $25.9 \mathrm{~nm}^{-1}$ for all the samples and no appreciable crystalline peak is observed. We have also confirmed the absence of appreciable crystalline phases in the optical micrographs and TEM images of the transverse cross section of the rod and sheet samples. Figure 2 shows DSC curves of the bulk glassy samples in the rod and sheet forms, together with the data of the corresponding melt-spun glassy ribbon. All of the DSC curves show nearly the same endothermic and exothermic reactions, i.e., the glass transition, followed by a large supercooled liquid region and then main exothermic peak due to crystallization. The feature of the DSC curves is almost independent of sample thickness. The $T_{\mathrm{g}}$ and $T_{\mathrm{x}}$ are 750 and $830 \mathrm{~K}$, respectively, and the $\Delta T_{\mathrm{x}}$ is as large as $80 \mathrm{~K}$ which is comparable to those $(70 \text { to } 127 \mathrm{~K})^{2)}$ for $\mathrm{Zr}-\mathrm{Al}-\mathrm{Ni}-\mathrm{Cu}$ glassy alloys. With the aim of determining the reduced glass transition temperature $\left(T_{\mathrm{g}} / T_{1}\right)$, we measured the $T_{1}$ value by DTA. As shown for the DTA curve in Fig. 3, the alloy solidifies though slightly divided two-stage exothermic reactions and the $T_{1}$ is determined as $1260 \mathrm{~K}$. The resulting $T_{\mathrm{g}} / T_{1}$ is evaluated to be 0.60 which is high enough to form a bulk glassy alloy by copper

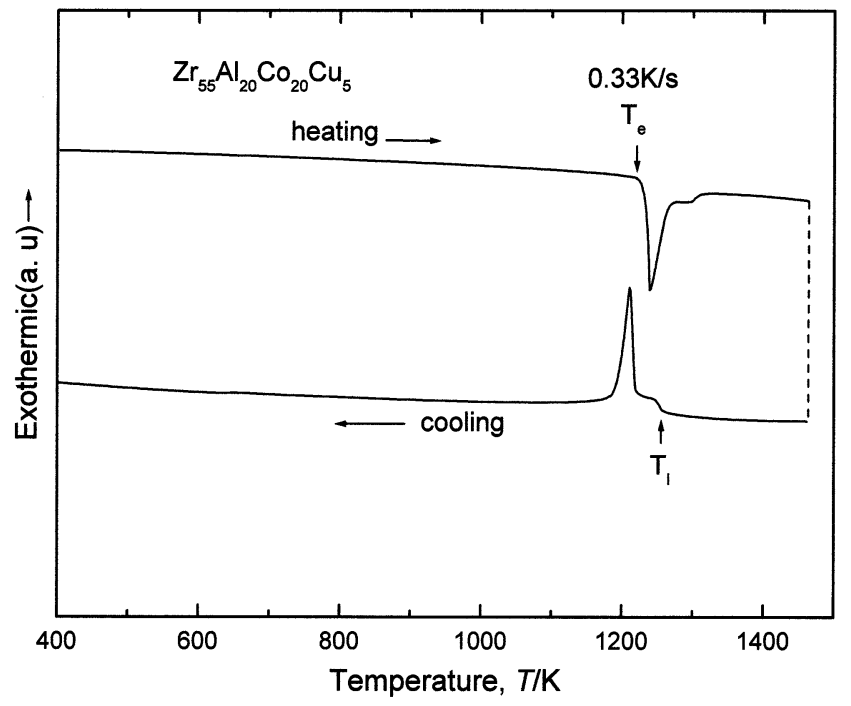

Fig. 3 DTA curve of a $\mathrm{Zr}_{55} \mathrm{Al}_{20} \mathrm{Co}_{20} \mathrm{Cu}_{5}$ alloy prepared by arc melting.

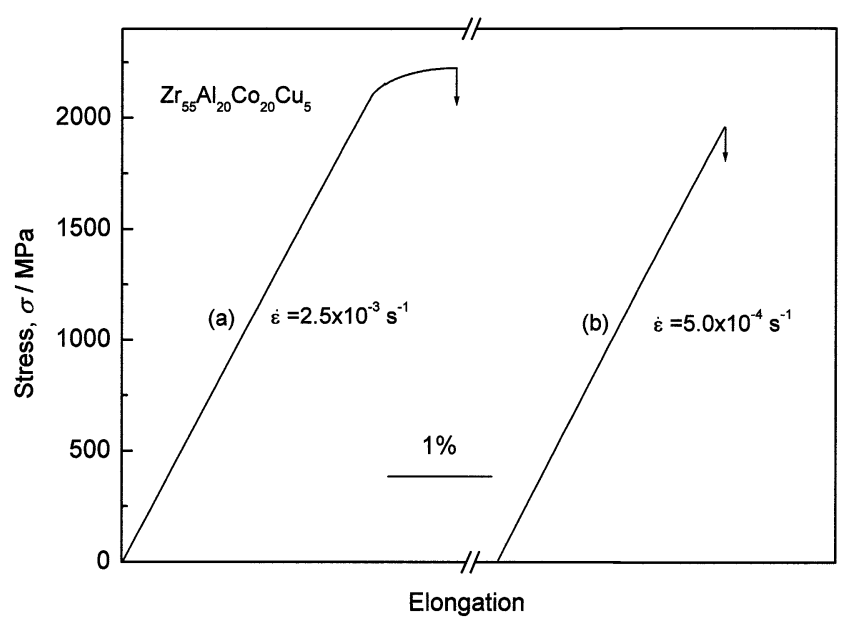

Fig. 4 Stress-elongation curves in tensile (a) and compressive (b) deformation modes for the glassy $\mathrm{Zr}_{55} \mathrm{Al}_{20} \mathrm{Co}_{20} \mathrm{Cu}_{5}$ alloy in a rod form of $2 \mathrm{~mm}$ in diameter and a sheet form of $1 \mathrm{~mm}$ in thickness.

mold casting, being consistent with the present results. The DTA data also imply that the elimination of the low intensity exothermic peak causes a significant decrease in $T_{1}$, leading to an increase of $T_{\mathrm{g}} / T_{1}$.

Figure 4 shows stress-elongation curves of the bulk glassy $\mathrm{Zr}_{55} \mathrm{Al}_{20} \mathrm{Co}_{20} \mathrm{Cu}_{5}$ samples in rod and sheet forms under tensile and compressive deformation modes. No distinct plastic elongation is seen in the tensile stress-elongation curve, but the compressive stress-elongation curve shows a distinct plastic elongation of about $0.6 \%$ before final fracture. The Young's modulus $(E)$, elastic elongation limit $\left(\varepsilon_{\mathrm{E}}\right)$, tensile fracture strength $\left(\sigma_{\mathrm{t}, \mathrm{f}}\right)$, compressive fracture strength $\left(\sigma_{\mathrm{c}, \mathrm{f}}\right)$ and total compressive fracture elongation including elastic elongation $\left(\varepsilon_{\mathrm{f}}\right)$ are $92 \mathrm{GPa}, 2.1 \%, 1960 \mathrm{MPa}, 2200 \mathrm{MPa}$ and $2.7 \%$, respectively. It is noticed that the tensile fracture strength reaches $1960 \mathrm{MPa}$ which is considerably higher than those $(1500 \text { to } 1700 \mathrm{MPa})^{7-10)}$ for the previously reported $\mathrm{Zr}$ based bulk glassy alloys in $\mathrm{Zr}-\mathrm{Al}-\mathrm{Ni}-\mathrm{Cu}, \mathrm{Zr}-(\mathrm{Ti}, \mathrm{Nb}, \mathrm{Pd})$ $\mathrm{Al}-\mathrm{Ni}-\mathrm{Cu}$ and $\mathrm{Zr}-\mathrm{Ti}-\mathrm{Ni}-\mathrm{Cu}-\mathrm{Be}$ systems. The fracture under the tensile or compressive deformation mode occurs along a maximum shear stress plane which is declined by about $45 \mathrm{de}-$ 


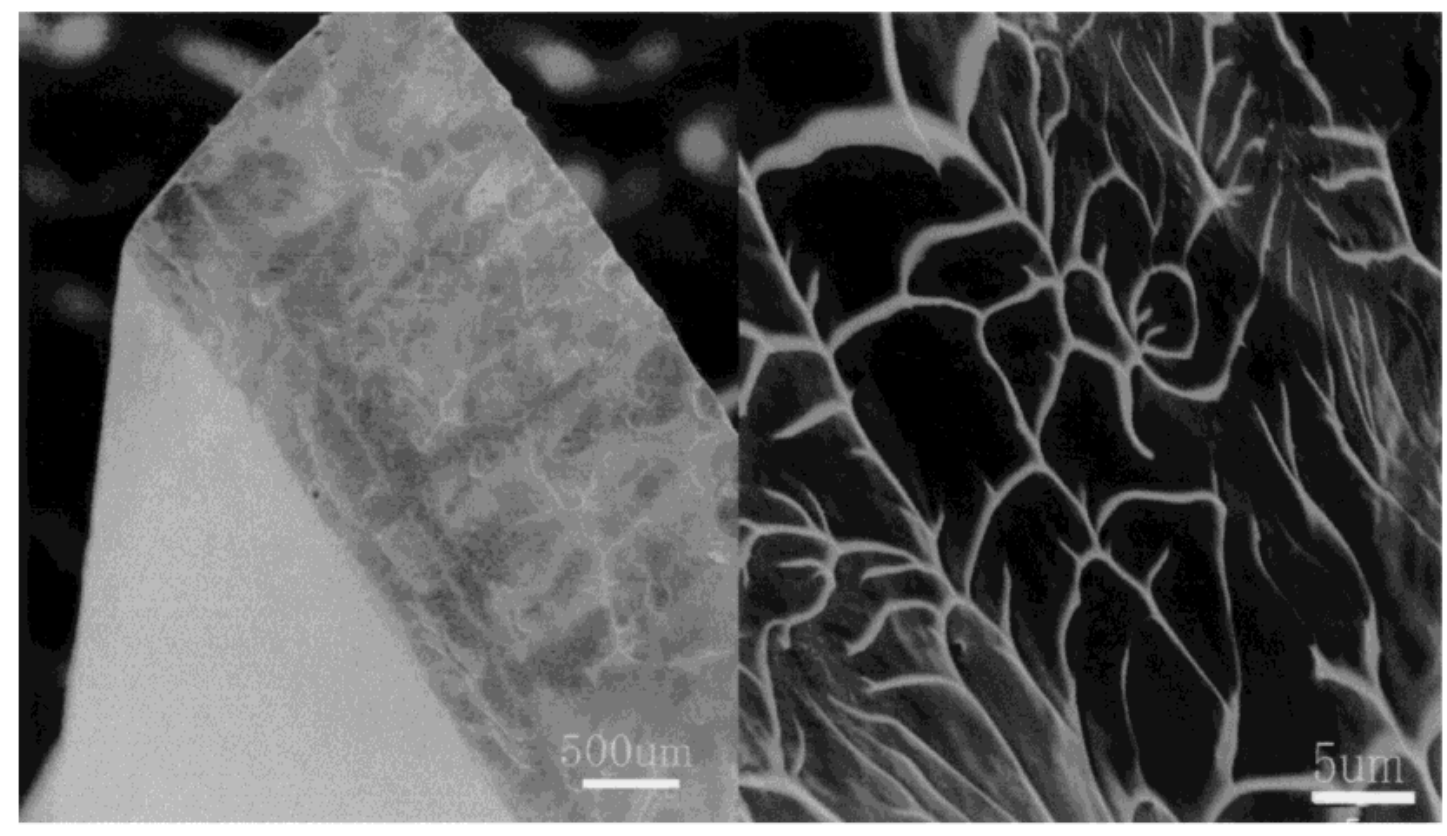

Fig. 5 Fracture surface of the glassy $\mathrm{Zr}_{55} \mathrm{Al}_{20} \mathrm{Co}_{20} \mathrm{Cu}_{5}$ alloy sheet subjected to fracture in a uniaxial tensile deformation mode.

grees to the direction of applied load and the fracture surface consists mainly of a well-developed vein pattern, as exemplified for the tensile fracture sheet in Fig. 5. The feature of the fracture mode agrees well with those for the other $\mathrm{Zr}$-based bulk glassy alloys.

\section{Discussion}

\subsection{High glass-forming ability}

As described in Section 1, a number of bulk glassy alloys have been synthesized in $\mathrm{Zr}$-based alloy systems. The alloy systems can be classified into two groups of $\mathrm{Zr}-\mathrm{Al}-\mathrm{Ni}-\mathrm{Cu}$ type including $\mathrm{Ti}, \mathrm{Nb}$, $\mathrm{Ta}$ and $\mathrm{Pd}$ as additional elements and $\mathrm{Zr}-\mathrm{Ti}-\mathrm{Ni}-\mathrm{Cu}-\mathrm{Be}$ type. ${ }^{7-10)}$ There have been no data on the formation of bulk glassy alloys in $\mathrm{Zr}-\mathrm{Al}-\mathrm{Co}$ base system and the $\mathrm{Al}$ content in the previously reported $\mathrm{Zr}-\mathrm{Al}-\mathrm{Ni}-\mathrm{Cu}$ bulk glassy alloys is usually in the range from 5 to 15 at $\%$. The higher $\mathrm{Al}$ content of 20 at $\%$ is another feature of alloy composition for the present $\mathrm{Zr}$-based alloy. Considering that the maximum sample diameter of the $\mathrm{Zr}_{55} \mathrm{Al}_{20} \mathrm{Co}_{20} \mathrm{Cu}_{5}$ glassy alloy is above $5 \mathrm{~mm}$ in the case of the copper mold casting method, the glass-forming ability is concluded to be comparable to those for the $\mathrm{Zr}-\mathrm{Al}-\mathrm{Ni}-\mathrm{Cu}$ and $\mathrm{Zr}-(\mathrm{Ti}, \mathrm{Nb}, \mathrm{Pd})-\mathrm{Ni}-\mathrm{Cu}$ systems. We consider the reason for the high glass-forming ability of the new $\mathrm{Zr}-\mathrm{Al}-\mathrm{Co}$ base alloy. It is thought that the base components in the present alloy are the three elements of $\mathrm{Zr}, \mathrm{Al}$ and $\mathrm{Co}$, though a small amount of $\mathrm{Cu}(5 \mathrm{at} \%)$ is included. It is known that all bulk glassy alloys in metal-metal type system have the following empirical component rules, i.e., (1) multi-component consisting of more than three elements, (2) significant difference in atomic size ratios above $12 \%$ among the main three constituent elements, and (3) suitable negative heats of mixing among the main elements. ${ }^{7-10)}$ The atomic size ratio is 1.12 for $\mathrm{Zr} / \mathrm{Al}, 1.14$ for $\mathrm{Al} / \mathrm{Co}$ and 1.28 for $\mathrm{Zr} / \mathrm{Co}{ }^{18)}$ and the heat of mixing is $-44 \mathrm{~kJ} / \mathrm{mol}$ for $\mathrm{Zr}-\mathrm{Al}$ pair, $-19 \mathrm{~kJ} / \mathrm{mol}$ for Al-Co pair and $-41 \mathrm{~kJ} / \mathrm{mol}$ for $\mathrm{Zr}-\mathrm{Co}$ pair. ${ }^{19)}$ These data clearly indicate that the $\mathrm{Zr}-\mathrm{Al}-\mathrm{Co}$ base alloy satisfies the above-described empirical component rules for formation of bulk glassy alloys as well as for stabilization of supercooled liquid. It has previously been reported that the bulk glassy alloys with the component rules can have a unique glassy structure with three features of (1) a higher degree of dense random packing state, (2) new local atomic configurations, and (3) long-range homogeneity with attractive interaction. ${ }^{9)}$ It is reasonably interpreted that the glassy alloy with such structural features can have a highly stable supercooled liquid state through high resistance against crystallization. The detailed mechanism for the stabilization of supercooled liquid has been described previously. ${ }^{9)}$

\subsection{High tensile strength}

It is shown in Fig. 4 that the tensile and compressive fracture strength values of the $\mathrm{Zr}_{55} \mathrm{Al}_{20} \mathrm{Co}_{20} \mathrm{Cu}_{5}$ alloy are $1960 \mathrm{MPa}$ and $2200 \mathrm{MPa}$, respectively. It is noticed that these strength values are much higher than those (1500 to $1800 \mathrm{MPa}$ ) for the previously reported Zr-based bulk glassy alloys in $\mathrm{Zr}-\mathrm{Al}-\mathrm{Ni}-\mathrm{Cu}, \mathrm{Zr}-(\mathrm{Ti}, \mathrm{Nb}, \mathrm{Pd})-\mathrm{Al}-\mathrm{Ni}-\mathrm{Cu}$ and $\mathrm{Zr}-$ Ti-Ni-Cu-Be systems. ${ }^{7-10}$ ) We discuss the reason for the higher tensile and compressive strength values of the present $\mathrm{Zr}-\mathrm{Al}-\mathrm{Co}-\mathrm{Cu}$ bulk glassy alloy. It has been pointed out that the tensile strength has a good linear relation with Young's modulus, $T_{\mathrm{g}}$ and liquidus temperature $\left(T_{1}\right)$ for bulk glassy alloys. ${ }^{14,19)}$ The Young's modulus, $T_{\mathrm{g}}$ and $T_{1}$ of the present $\mathrm{Zr}$ based alloy are $92 \mathrm{GPa}, 750 \mathrm{~K}$ and $1260 \mathrm{~K}$, respectively, being considerably higher than those $(89$ to $90 \mathrm{GPa}, 690 \mathrm{~K}$ and $1113 \mathrm{~K}$ ) for the other $\mathrm{Zr}$-based bulk glassy alloys. It is therefore concluded that the bonding force among the constituent elements in the $\mathrm{Zr}-\mathrm{Al}-\mathrm{Co}-\mathrm{Cu}$ glassy alloy is stronger than that for the other Zr-based glassy alloys. Considering the difference in the alloy components in these Zr-based glassy alloys, the stronger bonding force for the present alloy seems to be mainly attributed to the following two reasons, i.e., (1) the increase in the bonding numbers of $\mathrm{Zr}-\mathrm{Al}, \mathrm{Co}-\mathrm{Al}$ and $\mathrm{Cu}-\mathrm{Al}$ pairs resulting from the higher $\mathrm{Al}$ content (20 at \%) and (2) the 
larger average negative heats of mixing ( -19 to $-41 \mathrm{~kJ} / \mathrm{mol})$ for $\mathrm{Zr}-\mathrm{Co}$ and Al-Co pairs than those $(-1$ to $-49 \mathrm{~kJ} / \mathrm{mol})$ for $\mathrm{Zr}-\mathrm{Ni}, \mathrm{Zr}-\mathrm{Cu}, \mathrm{Al}-\mathrm{Ni}$ and $\mathrm{Al}-\mathrm{Cu}$ pairs. ${ }^{18)}$

\section{Summary}

A new Zr-based bulk glassy alloy with a diameter up to $5 \mathrm{~mm}$ was formed for the alloy component of $\mathrm{Zr}_{55} \mathrm{Al}_{20} \mathrm{Co}_{20} \mathrm{Cu}_{5}$ by copper mold casting. The $T_{\mathrm{g}}, \Delta T_{\mathrm{x}}$ and $T_{\mathrm{g}} / T_{1}$ of the bulk glassy alloy are $750 \mathrm{~K}, 80 \mathrm{~K}$ and 0.60 , respectively. The Young's modulus, elastic elongation limit, tensile fracture strength, compressive fracture strength and compressive plastic elongation are $92 \mathrm{GPa}, 2.1 \%, 1960 \mathrm{MPa}$, $2200 \mathrm{MPa}$ and $0.6 \%$, respectively. It is noticed that the tensile fracture strength is considerably higher than those (1500 to $1700 \mathrm{MPa}$ ) for the other Zr-based bulk glassy alloys. The higher strength combined with high glass-forming ability is promising as a new type of high-strength bulk glassy alloy.

\section{REFERENCES}

1) A. Inoue, T. Zhang and T. Masumoto: Mater. Trans., JIM 30 (1989) 965-972.

2) T. Zhang, A. Inoue and T. Masumoto: Mater. Trans., JIM 32 (1991) 1005-1010.

3) A. Inoue, T. Shibata and T. Zhang: Mater. Trans., JIM 36 (1995) 1420-
1426.

4) A. Peker and W. L. Johnson: Appl. Phys. Lett. 63 (1993) 2342-2344.

5) A. Inoue, Y. Yokoyama, Y. Shinohara and T. Masumoto: Mater. Trans., JIM 35 (1994) 923-926.

6) A. Inoue, T. Zhang, N. Nishiyama, K. Ohba and T. Masumoto: Mater. Trans., JIM 34 (1993) 1234-1237.

7) A. Inoue: Mater. Trans., JIM 36 (1995) 866-875.

8) A. Inoue: Acta Mater. 48 (2000) 279-306.

9) A. Inoue: Mater. Sci. Eng. A304-306 (2001) 1-11.

10) Supercooled Liquid Bulk Glassy and Nanocrystalline States of Alloys, ed. by A. Inoue, A. R. Yavari, W. L. Johnson and R. H. Dauskardt (MRS, Warrendale, 2001) pp. L12.13.1-L12.13.6.

11) A. Inoue, T. Nakamura, T. Sugita, T. Zhang and T. Masumoto: Mater. Trans., JIM 34 (1993) 351-358.

12) A. Inoue, N. Nishiyama and T. Matsuda: Mater. Trans., JIM 37 (1996) $181-184$

13) A. Inoue, W. Zhang, T. Zhang and K. Kurosaka: Acta Mater. 49 (2001) 2645-2652.

14) A. Inoue, W. Zhang, T. Zhang and K. Kurosaka: Mater. Trans. 42 (2001) $1142-1145$.

15) A. Inoue, W.Zhang, T. Zhang and K. Kurosaka: Mater. Trans. 42 (2001) 1149-1151.

16) A. Inoue, T. Zhang, K. Kurosaka and W. Zhang: Mater. Trans. 42 (2001) 1800-1804.

17) Metals Databook, ed. by Japan Inst. Metals, Maruzen, Tokyo (1983) p. 8.

18) F. R. Boer, R. Boom, W. C. M. Mattens, A. R. Miedema and A. K. Niessen: Cohesion in Metals, (North-Holland, Amsterdam, 1988) pp. 103-637.

19) H. S. Chen: Rep. Prog. Phys. 43 (1980) 353-432. 